\title{
Plant use in Muslim Spain: Preliminary results from the medieval town of Madīnat Ilbīra
}

\author{
MARIA LITYŃSKA-ZAJĄC ${ }^{1 *}$ and MARIAN RĘBKOWSKI ${ }^{2}$ \\ ${ }^{1}$ Institute of Archeology and Ethnology of the Polish Academy of Sciences, Centre for Archaeology of Hills \\ and Uplands, Sławkowska 17, 31-016 Kraków, Poland; e-mail: marialitynska@gazeta.pl; \\ https://orcid.org/0000-0002-6397-9805 \\ ${ }^{2}$ Institute of Archeology and Ethnology of the Polish Academy of Sciences, Centre for Medieval Archaeology \\ of the Baltic Region, Kuśnierska 12/12a, 70-536 Szczecin, Poland; e-mail: m.rebkowski@iaepan.szczecin.pl; \\ https://orcid.org/0000-0001-9585-7688
}

Received 24 June 2020; accepted for publication 2 December 2020

\begin{abstract}
The paper presents preliminary results of archaeobotanical studies carried out at the Madīnat Ilbīra site in Spain. The functioning of the town, which was the capital of one of the administrative districts (küras) of alAndalus, falls in the period between the second half of the $9^{\text {th }}$ century and the $11^{\text {th }}$ century. However, the analysed soil samples were collected from archaeological contexts dated mostly to the last decades of the $10^{\text {th }}$ century and to the $11^{\text {th }}$ century. The samples yielded an interesting set of data about the preserved plant remains. Although the taxonomic diversity of the plants is not high, the analysis revealed remains of naked and hulled wheat (emmer wheat), millet, poppy seeds, perhaps peas, cucumber or melon, and grapevine. Although crop plants played an important role in the everyday diet of the town inhabitants, wild plants also were probably collected and used. The latter are represented in the analysed materials by, for example, wild strawberry, common mallow and common purslane. The preserved charcoal remains confirm the use of different species of wood as fuel.
\end{abstract}

KEYWORDS: medieval period, Islamic town, cereals, wild plants, Iberian Peninsula

\section{INTRODUCTION}

The literature reflects a well-established conviction that the Islamic period in the Iberian Peninsula, which started with the $711 \mathrm{AD}$ conquest, played a key role in the history of farming. The new model of farming and new irrigation systems resulted in changes sometimes referred to as a "green revolution" (Watson, 1983; Malpica Cuello, 2012b). At the same time, the suggestion that one element of these changes was the introduction of new crops to the peninsula (e.g. Decker, 2009) is sometimes questioned. In this discussion, the results of archaeological excavations and archaeobotanical studies have been used to a limited extent, primarily dictated by the degree of advancement of Islamic archaeology in Spain and

\footnotetext{
Corresponding author
}

Portugal. A recently published evaluation of the current state of archaeobotanical research employed materials obtained from twenty archaeological sites associated with Muslim settlement in the Iberian Peninsula dated to the $8^{\text {th }}-13^{\text {th }}$ centuries (Peña-Chocarro et al., 2019), including from several towns.

The network of towns that formed during the $9^{\text {th }}$ and $10^{\text {th }}$ centuries, which were of various origins, played a material role in the economy and culture of Muslim Spain. One such early Islamic town was Madinnat Ilbīra, located in the southeastern part of the Iberian Peninsula, on the Plain of Granada (Fig. 1). For a while the town was the capital of one of the administrative districts (küras) of al-Andalus. Its origin and dating are sometimes disputed. Written records and results of archaeological excavations 


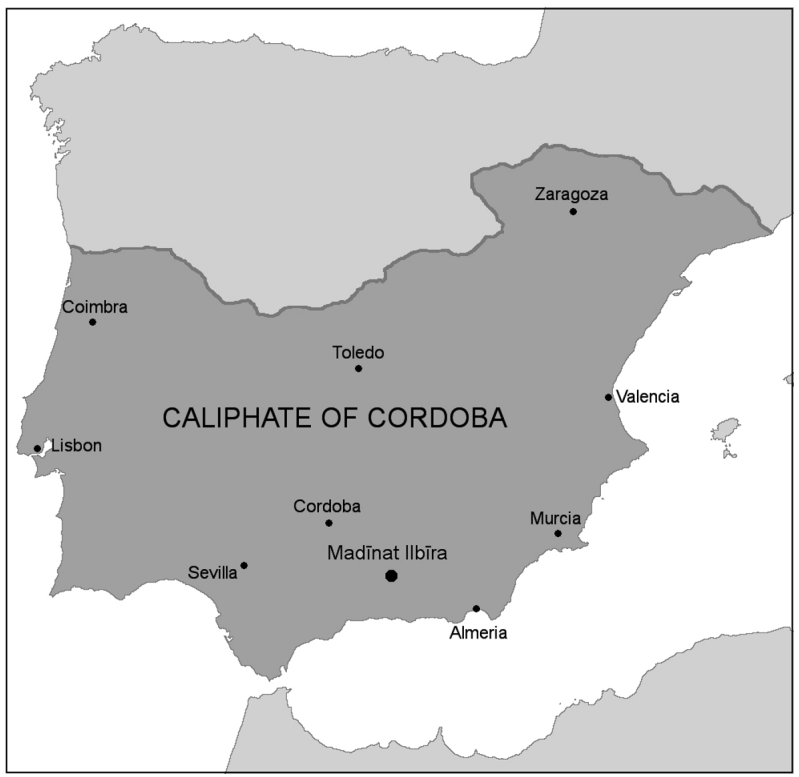

Fig. 1. Location of Madinat Ilbīra on map of the Caliphate of Córdoba, c. $1000 \mathrm{AD}$

carried out to date allow us to state that it was established no later than around the mid- $9^{\text {th }}$ century, whereas the period of its depopulation and decline dates to around the mid- $11^{\text {th }}$ century and is associated with the downfall of the Caliphate of Córdoba (Malpica Cuello, 2011, 2012a; Espinar Moreno, 2016), when the main economic and administrative centre of that region became neighbouring Granada.

The main aim of the archaeobotanical research undertaken in Madīnat Ilbīra a few years ago was to identify the flora and vegetation in the vicinity of the medieval settlement. However, this paper aims only to present the economic importance of the used plants, both cultivated and wild, for the inhabitants of the town. "Determining the role played by individual plant species in ancient husbandry is forever problematic, hence present-day use (potential usefulness of species) remains a basic criterion for assessing the economical usefulness of a given species (according to the principle of uniformitarianism)" (Lityńska-Zając, 2008: 107, see also Collegde and Conolly, 2014; Lityńska-Zając, 2018).

\section{THE SITE}

The archaeological site covering the remains of the town of Madinat Ilbirra is located around $10 \mathrm{~km}$ to the west of modern-day Granada, at the foot of the Sierra Elvira mountain range, and extends more than 30 hectares (Figs 2, 3).
We owe the primary data concerning the town to chance discoveries and searches carried out in that area as early as in the $19^{\text {th }}$ century (Gomez Moreno, 1888). The first modern excavations, initially performed on a very limited scale, did not take place until the beginning of the $21^{\text {st }}$ century (Malpica Cuello, 2012c). As a result, archaeologists identified the location of the fortress and unearthed fragments of the adjacent town buildings. During these excavations the first archaeobotanical samples were taken. In analyses of macroscopic plant remains from twelve samples, the presence of naked wheat (Triticum aestivum/durum), barley (Hordeum vulgare) and olive (Olea europaea) was documented in almost all samples (Peña-Chocarro, 2013).

A new stage in the investigations of the town began in 2016, together with the commencement of a large-scale non-invasive survey and archaeological excavations carried out as a part of the project called "Madinnat Ilbīra - the predecessor of Granada. The medieval Umayyad and Mozarabic town in the Iberian Peninsula". One outcome of these investigations was to obtain several dozen samples for botanical analyses from well-dated settlement contexts. The largest group of them was taken from trenches excavated in the eastern part of the town, several hundred meters away from the fortress and the location of the main town mosque (Fig. 2). A chance find in the $19^{\text {th }}$ century, and nearby burials recorded in this century during work related to the construction of modern infrastructure (sewage system), led researchers to suggest that the area could be the location of a district occupied by local Christians, the Mozarabs. Symbols of Christian worship discovered during the excavations support that hypothesis.

The excavations revealed densely sited, regularly planned masonry buildings in that part of the town (Fig. 4), the construction of which was preceded by the creation of ditches and wells for distribution of water (qanat). The assemblages of finds discovered at the site, sherds of pottery in particular and especially a very large series of radiocarbon dates, make it possible to date the settlement in that part of the town quite precisely to the period between the second half of the $10^{\text {th }}$ century, most probably the last decades of that century, and the end of the $11^{\text {th }}$ century. This means that its establishment fell in the period of the heyday 


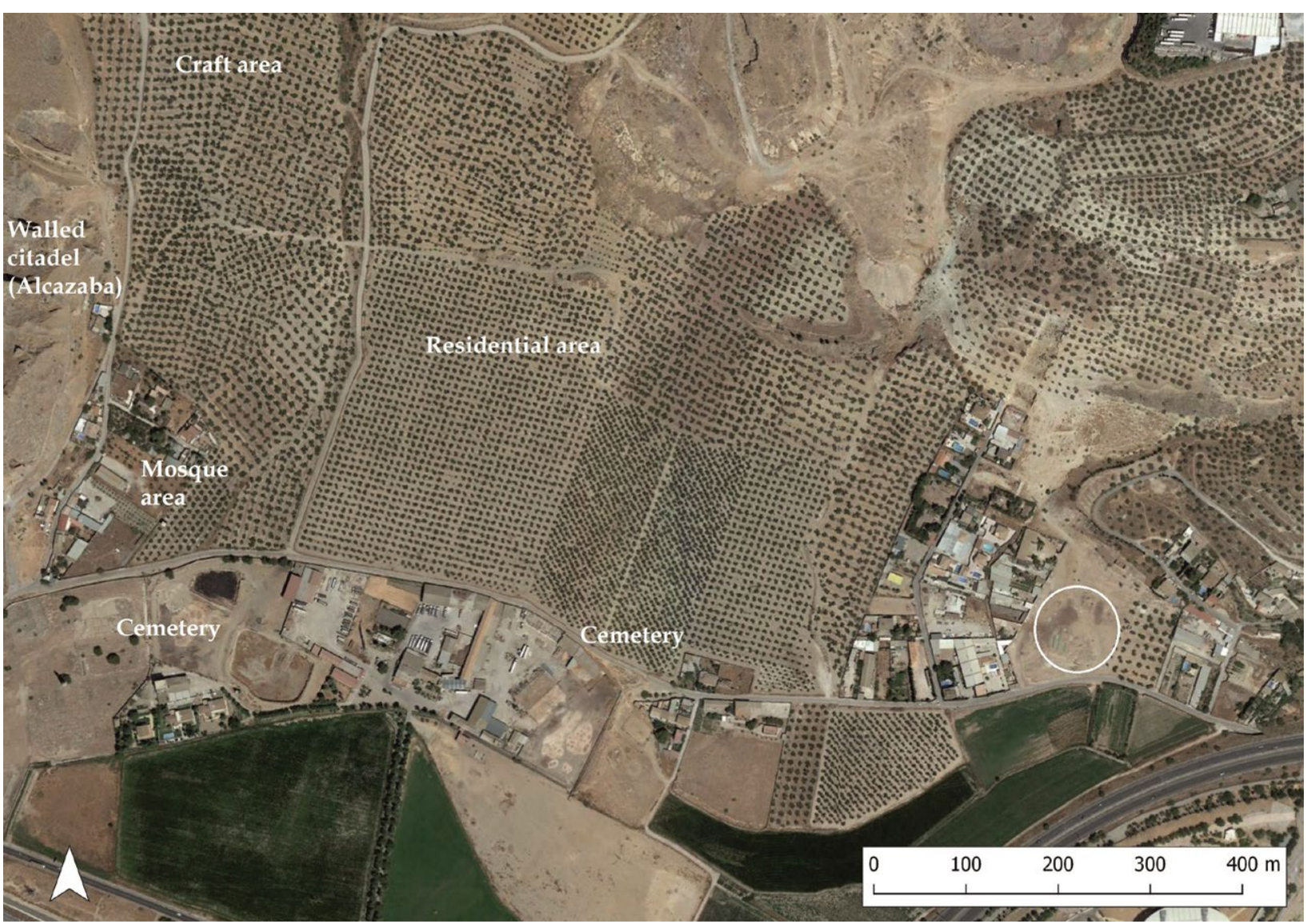

Fig. 2. Location of the recognized spatial elements of medieval Madinnat Ilbīra, according to Malpica Cuello, 2012c. The excavation area within the assumed Mozarab district is circled

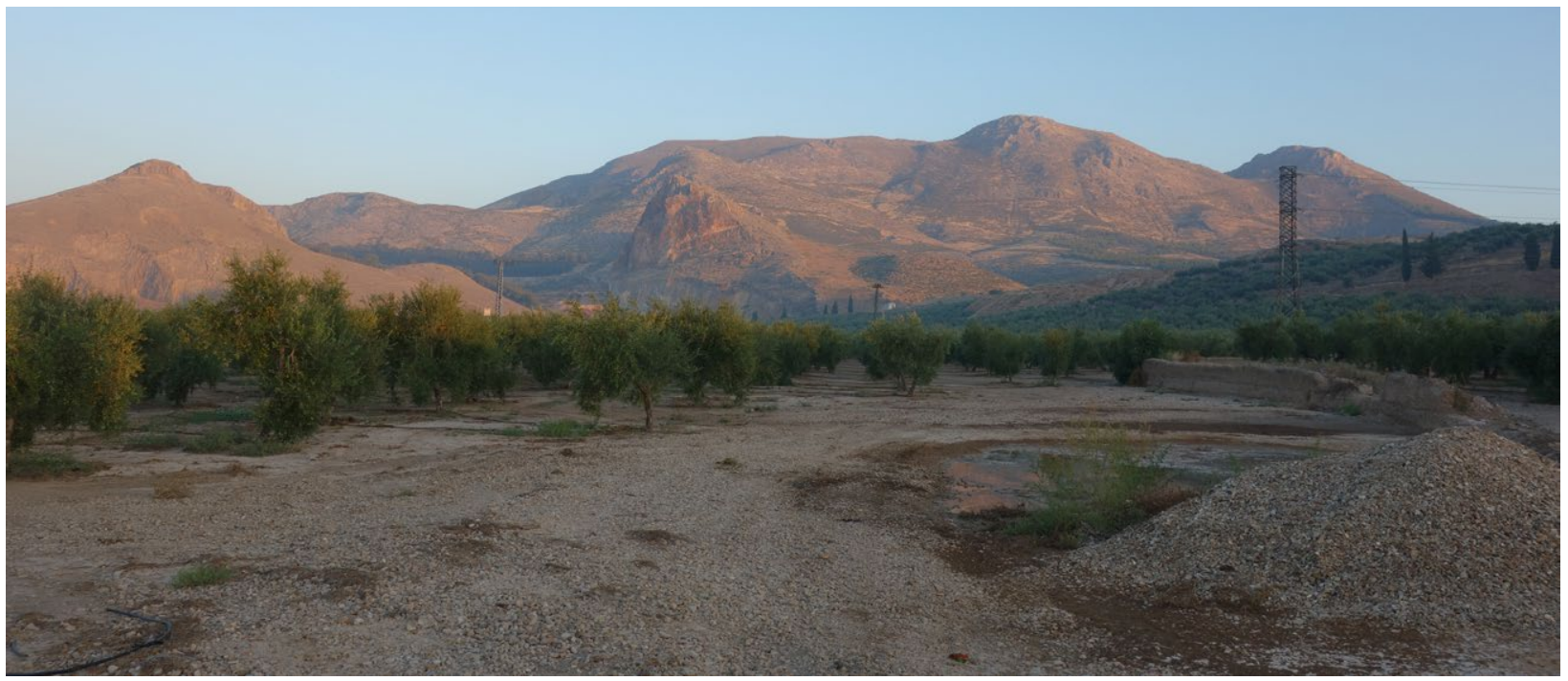

Fig. 3. View of the area of the site situated at the foot of Sierra Elvira. On the slope of El Sombrerete hill (left), remains of the citadel were identified. Photo by Marian Rębkowski

of the Caliphate of Córdoba, and depopulation of the town proceeded several decades after its downfall and the emergence of the new urban centre in nearby Granada. It was also established that some sort of settlement, most probably of rural character, existed at the site of the former town at the end of the Middle Ages, most probably in the $13^{\text {th }}-14^{\text {th }}$ centuries.

\section{MATERIALS AND METHODS}

Thirty-nine soil samples randomly taken during the excavations were submitted for botanical studies. The vast majority came from cultural layers associated with the existence of the town and dated between the second half of the $10^{\text {th }}$ century and the end of the $11^{\text {th }}$ century; only a few of them were dated to a later period. Most of the samples were taken from domestic contexts and 


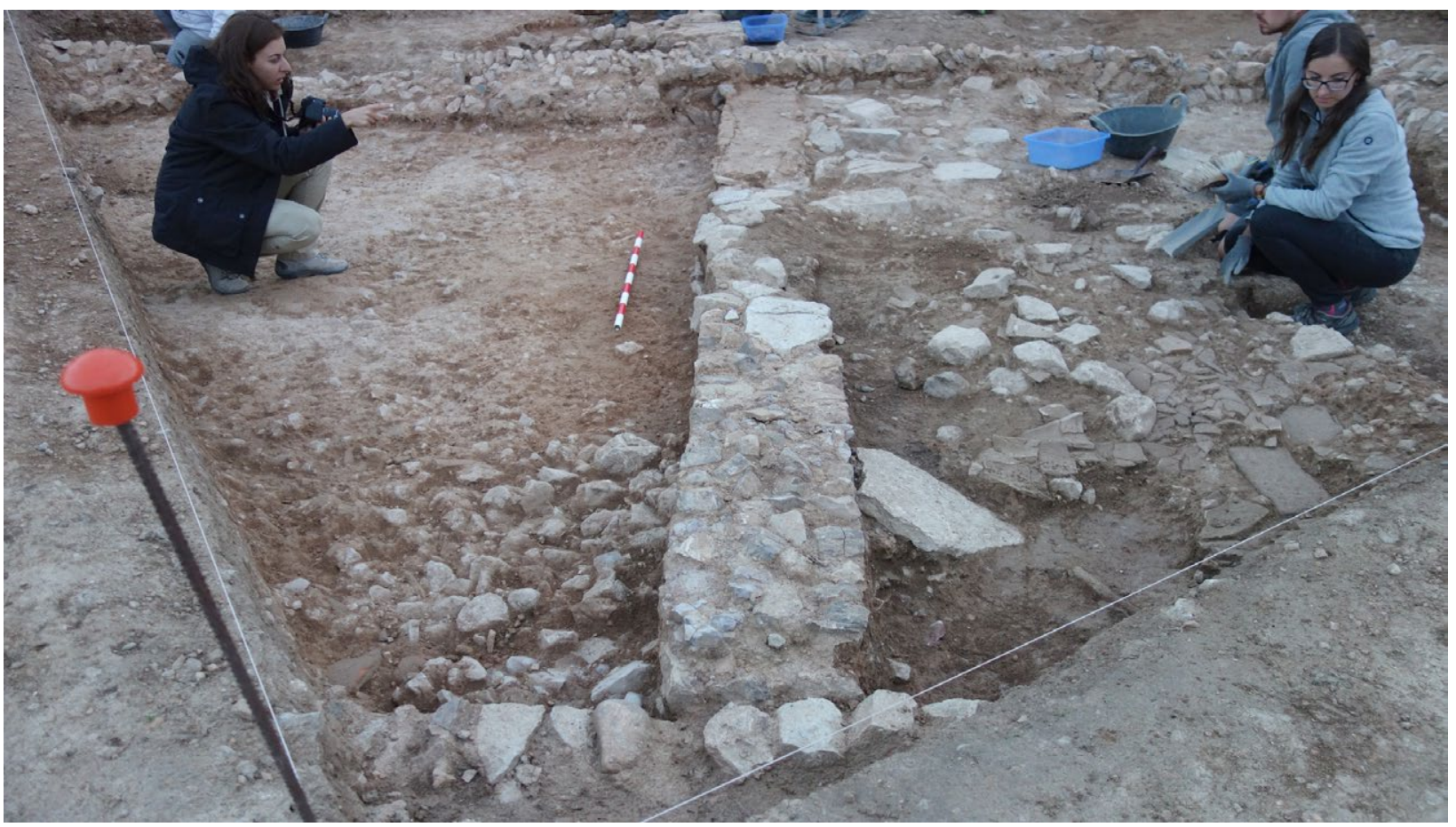

Fig. 4. Exploration of remains of a building structure dated to the end of the $10^{\text {th }}$ century. Photo by Marian Rębkowski

only a few of them were collected from wells related to the qanat system. Each sample, which ranged in volume from $0.5 \mathrm{l}$ to $10 \mathrm{l}$, was subjected to flotation; the light fraction was repeatedly separated and collected using $0.2 \mathrm{~mm}$ and $0.5 \mathrm{~mm}$ sieves. The two fractions obtained through water sieving were separated while still wet with the use of a low-power stereomicroscope at $10 \times$ magnification. Then all organic remains were removed and segregated. Fruit and seeds, numerous wood fragments, vegetative parts of plants, snail shells and small bone fragments were then identified in the material. Only one sample (Inv. GR-MI-18 III 42.037a), which came from the fill of an access shaft of the qanat irrigation system, did not contain any plant remains. One sample (Inv. GR-MI-19 III 41.120) contained contemporary contamination in the form of uncharred caryopses of grasses (Poaceae indet.) and fruit of Viola sp. which began to germinate several days after being watered (Lityńska-Zając and Wasylikowa, 2005: 41, 42). That sample came from a stratigraphic unit that was partly damaged by modern human activity.

The preserved plant remains were in the form of charred and uncharred specimens, including mainly mineralised ones. Charred remains were represented primarily by fragments of wood and some caryopses of crops (cereal); some of the fruits and seeds were mineralised (e.g. Fumaria officinalis) or occurred in both abovementioned forms (e.g. Vitis vinifera seeds). Uncharred remains contained specimens mineralised (e.g. seeds of Heliotropium europaeum) and dried (e.g. stem fragments of Poaceae indet.). It is supposed that charring of plant remains could have occurred in two ways: in the course of food preparation, or unintentionally during a fire destroying this part of the settlement. Mineralised specimens were filled with mineral compounds due to permineralisation (see Discussion below). The presence of dried remains was caused by dry climate conditions and a continuous lack of moisture, which prevents the destructive action of bacteria and fungi. In such a state of preservation there were even very delicate parts of plants that can be damaged by other processes of fossilization (e.g. vegetative parts of plants). The retrieved plant remains (fruit, seeds, and vegetative parts of herbaceous plants) were usually well-preserved. Some diaspores bore evidence of mechanical damage, which obliterated some morphological features and made it difficult or impossible to classify them.

Well-preserved charcoals usually had clearly visible anatomical structure. Individual specimens were strongly vitrified, most probably as a result of burning damp wood at high temperature (Lityńska-Zając, Wasylikowa, 2005: 208). There was a large share of highly fragmented overburnt wood. These remained unclassified, as the degree of identification of individual charcoal fragments depends on their size, wood anatomical structure and preservation state (Schweingruber, 1982; Chabal et al., 1999).

The sediment of one of the samples (Inv. GR-MI-18 III 41.021) contained 11 fragments of roof tiles. Individual pieces varied in size (the longest ranging from $2 \mathrm{~cm}$ to $10 \mathrm{~cm}$ ), with a flat, orange surface, well-fired and relatively hard. Another sample (Inv. GR-MI-19 III 41.120) contained nine small fragments of burnt orange clay (daub). First the surface of lumps of brick and burnt clay was analysed, and after recording all plant traces they were broken to search for potential plant remains inside them.

Fruit and seeds and imprints of plant material preserved in clay were identified and classified on the basis of their morphological characteristics, using specialist guides and botanical atlases (e.g. Dörter, 1968; Cappers et al., 2006; 2009; Jacomet, 2006; Neef et al., 2011). In each case, the results were compared with the reference collections of modern and fossil diaspores stored in the Archaeological Laboratory of the Institute of Archaeology and Ethnology of the Polish Academy 
of Sciences in Igołomia and in the Department of Palaeobotany of the W. Szafer Institute of Botany, Polish Academy of Sciences. Laboratory analyses employed a Nikon low-power stereomicroscope at $40 \times$. Selected specimens were measured with a Brünell micrometre to the nearest $0.1 \mathrm{~mm}$.

Burnt wood specimens were classified on the basis of anatomical features. For microscopy, fresh fractures were made in three anatomical sections of wood characteristic for the botanical material: one transverse and two longitudinal (tangential and longitudinal radial), and these observations were cross-referenced with publications on plant anatomy (Esau, 1973; Schweingruber, 1978, 1990a, 1990b; Carrión Marco, 2005). Additionally, taxonomic identifications were made by comparison with a modern wood collection. Analyses were carried out with a Nikon metallographic reflected light microscope at $500 \times$.

\section{RESULTS}

According to our preliminary results, the material contained preserved remains of various cereals: one of two species of naked wheat - durum or bread wheat (Triticum durum Desf. vel T. aestivum L.; Pl 1, fig. 1), hulled wheat emmer wheat (T. dicoccon Schrank.; Pl. 1, fig. 2) and broomcorn millet (Panicum miliaceum L.) (Tab. 1). Remains of those plants occurred as charred caryopses, which in the case of naked wheat made it impossible to distinguish the two taxons only by the caryopses (Lityńska-Zając and Wasylikowa, 2005: 81; Jacomet, 2006). Remains of emmer wheat were also preserved as basal parts of spikelets (spikelet forks). The samples also contained caryopses and chaff fragments which due to their state of preservation were generally classified as unidentified cereals (Cerealia indet.). Other identified plants included seeds of cucumber or melon (Cucumis sativus L. vel C. melo L.), poppy (Papaver somniferum L.) and grapevine (V. vinifera $\mathrm{L}$. subsp. vinifera; Pl. 1, figs 3, 4). It should be stressed that fossil seeds of cucumber cannot be reliably distinguished from fossil melon seeds (Bates and Robinson, 1995). Recent studies on seed morphology indicate that "Seeds of each of the four taxa (Cucumis melo, C. sativus and Citrullus colocynthis, C. lanatus) are clearly grouped and the distance between the two genera, Cucumis and Citrullus, is higher than that between the two species within the same genus. C. colocynthis and C. lanatus seeds are more distant than $C$. melo and $C$. sativus seeds" (Sabato et al., 2015: 444). Considering the above, and the fact that only one specimen was preserved, it was determined as Cucumis sativus vel C. melo ( $\mathrm{Pl}$. 1, fig. 5). Perhaps we should also count among the crop plants a pea seed identified to genus level (Pisum sp.). That specimen does not have the seed coat, so we could not determine its taxonomic classification more precisely.

In the group of herbaceous plants there were remains of wild strawberry (Fragaria vesca L.; Pl. 1, fig. 6), common fumitory (Fumaria officinalis L.), purslane (Portulaca oleracea L.), white goosefoot (Chenopodium t. album L.), oak-leaved goosefoot (Chenopodium glaucum L.), charlock mustard (Sinapis arvensis L.), common mallow (Malva sylvestris L.; Pl. 1, fig. 7), barnyard millet (Echinochloa crus-galli (L.) P.Beauv.), cinquefoils (Potentilla sp.) and grasses (Poaceae indet.).

The antracological spectrum showed wood pine (Pinus sp.), including most probably Italian stone pine (Pinus cf. pinea), and also deciduous oak (Quercus sp.), ash (Fraxinus sp.) and some undetermined rosaceous plants (Rosaceae indet.).

\section{DISCUSSION}

The remains of the above-mentioned species were scattered among different archaeological features. Mineralised specimens (e.g. Vitis vinifera and Fumaria officinalis) were concentrated mainly in the sample labelled GR-MI-18 III 42.037, which came from another access shaft of the qanat. Most probably they were deposited there by accident and their tissues became permineralised (Lityńska-Zając and Wasylikowa, 2005: 43) with, for example, calcium compounds. It is also possible that they were intentionally added to mortar during its preparation. Plant materials have been found in adobe bricks, clay and other construction materials in dry areas such as in Egypt (Marinova et al., 2012). Charred remains of i.a. cereals occurred in samples (Inv. GR-MI-18 III 41.080 and III 41.080.1) from the fill of a sunken stove, consisting of ash with clayey fractions. The state of preservation of the plant remains conforms to the nature of the archaeological feature.

Individual roof tile fragments contained a few imprints, mostly as negative impressions, but there were also several positive imprints. There were imprints close to caryopses of Panicoideae grasses in shape and size. That group 
Table 1. List of plant remains preserved in Madīnat Ilbīra. State of preservation: ch - charred, unch - uncharred, im - imprint

\begin{tabular}{|c|c|c|c|c|}
\hline \multirow{2}{*}{ Taxon } & \multirow{2}{*}{$\begin{array}{c}\text { State } \\
\text { of preservation }\end{array}$} & \multirow{2}{*}{$\begin{array}{l}\text { Kind } \\
\text { of remains }\end{array}$} & \multicolumn{2}{|c|}{ Number of } \\
\hline & & & specimens & samples \\
\hline \multicolumn{5}{|l|}{ Cereals } \\
\hline Panicum miliaceum & $\mathrm{ch}$ & caryopsis & 1 & 1 \\
\hline Triticum aestivum vel. T. durum & $\mathrm{ch}$ & caryopsis & 8 & 4 \\
\hline Triticum dicoccon & $\mathrm{ch}$ & caryopsis & 2 & 1 \\
\hline Triticum dicoccon & $\mathrm{ch}$ & spikelet fork & 2 & 1 \\
\hline Cerealia indet. & $\mathrm{ch}$ & caryopsis & 5 & 4 \\
\hline Cerealia indet. & $\mathrm{ch}$ & chaff & 1 & 1 \\
\hline Cerealia indet. vel Poaceae indet. & $\mathrm{im}$ & chaff & few & 1 \\
\hline \multicolumn{5}{|l|}{ Other cultivated plants } \\
\hline Cucumis sativus vel C. melo & unch & seed & 1 & 1 \\
\hline Papaver somniferum & $\mathrm{ch}$ & seed & 12 & 2 \\
\hline Vitis vinifera subsp. venifera & unch & seed & 26 & 3 \\
\hline Vitis vinifera subsp. venifera & $\mathrm{ch}$ & seed & 4 & 1 \\
\hline Pisum sp. & $\mathrm{ch}$ & seed & 1 & 1 \\
\hline \multicolumn{5}{|l|}{ Wild plants } \\
\hline Chenopodium t. album & $\mathrm{ch}$ & seed & 45 & 3 \\
\hline Chenopodium glaucum & unch & seed & 1 & 3 \\
\hline Echinochloa crus-galli & unch & caryopsis & 1 & 1 \\
\hline Fragaria vesca & unch & seed & 17 & 1 \\
\hline Fumaria officinalis & unch & fruit & 20 & 2 \\
\hline Galium aparine & $\mathrm{ch}$ & fruit & 1 & 1 \\
\hline Heliotropium europaeum & unch & seed & 31 & 2 \\
\hline Hypericum perforatum & $\mathrm{ch}$ & seed & 1 & 1 \\
\hline Malva sylvestris & unch & seed & 1 & 1 \\
\hline Myosotis arvensis & unch & seed & 1 & 1 \\
\hline Polygonum persicaria & unch & fruit & 1 & 1 \\
\hline Portulaca oleracea & unch & seed & 12 & 1 \\
\hline Rumex acetosa & unch & fruit & 1 & 1 \\
\hline Sinapis arvensis & unch & seed & 2 & 1 \\
\hline Urtica urens & unch & fruit & 1 & 1 \\
\hline Chenopodium sp. & $\operatorname{ch}$ & seed & 3 & 3 \\
\hline Chenopodium sp. & unch & seed & 2 & 1 \\
\hline Malva sp. & $\mathrm{ch}$ & fruit & 1 & 1 \\
\hline Polygonum sp. & unch & fruit & 1 & 1 \\
\hline Potentilla sp. & unch & seed & 1 & 1 \\
\hline Rumex sp. & unch & fruit & 3 & 1 \\
\hline Viola sp. & unch & fruit & 3 & 2 \\
\hline Boraginaceae indet. & $\mathrm{ch}$ & fruit & 1 & 1 \\
\hline Caryophyllaceae indet. & unch & seed & 1 & 1 \\
\hline Panicoideae indet. & $\mathrm{im}$ & caryopsis & 5 & 1 \\
\hline Poaceae indet. & $\mathrm{im}$ & chaff & 4 & 1 \\
\hline Poaceae indet. & unch & stem & 20 & 1 \\
\hline \multicolumn{5}{|l|}{ Trees and shrubs } \\
\hline Pinus cf. pinea & $\mathrm{ch}$ & wood & 6 & 1 \\
\hline Fraxinus sp. & $\mathrm{ch}$ & wood & 2 & 1 \\
\hline Fraxinus sp. & unch & wood & 1 & 1 \\
\hline Pinus sp. & $\mathrm{ch}$ & wood & 3 & 2 \\
\hline Quercus sp., deciduous & $\mathrm{ch}$ & wood & 6 & 2 \\
\hline Rosaceae indet. & $\mathrm{ch}$ & wood & 5 & 1 \\
\hline \multicolumn{5}{|l|}{ Other plant remains } \\
\hline Dicotolydones & unch & leaf & 1 & 1 \\
\hline undetermined & $\mathrm{ch}$ & $?$ & 1 & 1 \\
\hline undetermined & $\mathrm{ch}$ & seed & 6 & 1 \\
\hline undetermined & unch & stem & 4 & 1 \\
\hline Total & & & 279 & \\
\hline
\end{tabular}


includes such genera as millet (Panicum), Echinochloa, Digitaria and Setaria. Since the sediment from that sample contained caryopses of Echinochloa crus-galli, we may assign those imprints to that species. Among the imprints there were also smaller and larger fragments of chaff representing cultivated or wild grasses - Cerealia indet. vel Poaceae indet. In addition to those there were also shallow lenticular indentations with a smooth surface and thus devoid of diagnostic features. These specimens remained unclassified. Strongly overburnt, shapeless and unidentified organic matter was inside lumps of burnt clay.

Despite the preservation of only a small quantity of plant remains, we can state that the people who lived in Madinnat Ilbīra used at least three different species of cereals: one or both naked wheat species, emmer wheat and broomcorn millet. The caryopses of bread wheat (Triticum aestivum) are high in starch and gluten and thus provide very good quality flour. They are suitable for baking bread and cakes and for making pasta and groats, while their use for brewing beer is very limited. Bran is relatively high in protein and fat, which makes it a good addition to cattle feed (Körber-Grohne, 1988). Durum wheat (T. durum) has hard grains which are difficult to grind. It yields flour that is particularly good for making pasta and for baking bread (yellowish in colour) which keeps better than bread baked with bread wheat flour (Percival, 1921). Emmer wheat grain (Triticum dicoccon) was used primarily for making highquality groats and pasta, and only rarely to produce flour for breadmaking. Spikelets were also added to horse feed. One use of thick straw was for thatching (Lityńska-Zając and Wasylikowa, 2005: 77). Millet caryopses were used in many different ways. In Europe they were usually consumed as groats. However, according to Columella and Pliny, authors from the period of the Roman Empire (citation after Körber-Grohne, 1988), in the past people ate both groats and bread baked from millet flour. "In Asia, in addition to groats, people use flour made from millet and foxtail millet to prepare a special dish with milk or fat, and varieties with higher gluten content for baking bread" (Lityńska-Zając and Wasylikowa, 2005: 106). The grain was used for feeding birds and poultry. Millet was also an ingredient for beer and vodka production (Hanelt, 2001). Straw also served as fodder and as bedding for breeding animals, and as insulation for covering various piles and heaps. Unequivocal evidence of the use of straw and other remains from threshing as a temper added to construction clay is provided by floral imprints of those plant parts in roof tile fragments. It was also used for constructing walls of buildings in the tapial technique, where parts of walls above stone foundations were constructed inside a wooden form by packing down layers of clay, sand and organic materials (Gurriarán Daza and Sáez Rodríguez, 2002).

Naked wheat (Triticum aestivum vel T. durum), recorded in archaeological material from Spain since the beginning of the Neolithic, was a particularly important crop in the Middle Ages (Peña-Chocarro et al., 2019). Emmer wheat (T. dicoccon), the main cereal of the Neolithic (e.g. Buxó, 2007; PeñaChocarro, 2007), gradually lost its importance in subsequent chronological periods, so that in medieval crop farming it played only a marginal role (Buxó Capdevila et al., 1997). At the same time, broomcorn millet (Panicum miliaceum), which appears in crops cultivated in the Bronze Age, gained importance in the Middle Ages (Peña-Chocarro et al., 2019).

Other crop plants no doubt were also used in households. The opium poppy Papaver somniferum is an oleaginous plant; poppy oil is extracted from the seeds. It is palatable and is sometimes used in confectionery. Due to high content of alkaloids (e.g. morphine, codeine, papaverine), the seeds have medicinal properties, primarily pain-relieving and narcotic (opium). Poppy press cake, the residue of oil pressing, is a good concentrated animal feed (Körber-Grohne, 1988; Lityńska-Zając and Wasylikowa, 2005: 129; Zohary et al., 2012: 108).

Grape cultivation provides fresh and dried fruit (raisins) and raw material for making wine, vinegar and oil, and the press cake is used as fodder and fertilizer (Zohary et al., 2012: 121; Lityńska-Zając and Wasylikowa, 2005: 141). The beginning of Vitis vinifera cultivation in Spain is dated to around 1000 $\mathrm{BC}$; since then, it has been an important plant commonly cultivated in the Middle Ages (PeñaChocarro et al., 2019).

Remains of cucumber or muskmelon (Cucumis sativus vel C. melo) such as were found at Madinat llbīra have been recorded in other medieval material from Spain (PeñaChocarro et al., 2019). Unfortunately, as 

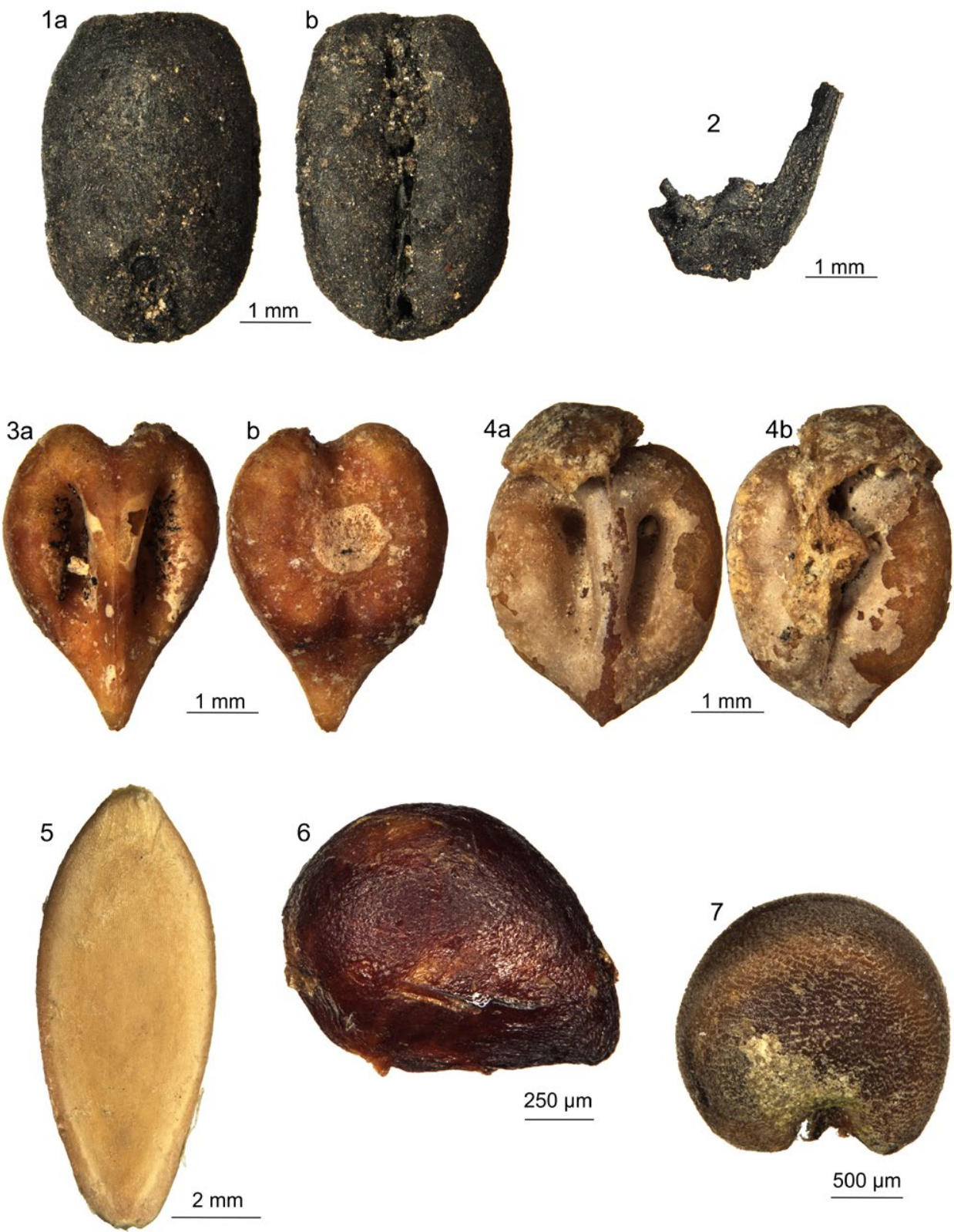

Plate 1. Macroscopic plant remains from Madinnat Ilbīra (Photo Krzysztof Stachowicz, compiled by Katarzyna Cywa). 1. Triticum aestivum or T. durum - caryopsis, a. dorsal view, b. ventral view; 2. Triticum dicoccon - basal part of spikelet; 3, 4. Vitis vinifera subsp. Vinifera - pipes, a, b. fruit-stone from both sides (two specimens); 5. Cucumis sativus vel C. melo; 6. Fragaria vesca; 7. Malva sylvestris

mentioned above, it is not possible to determine which of the two species was preserved at the site. Arabic medical treatises suggest the presence of cucumbers in Spain by the mid-9 $9^{\text {th }}$ century (Paris et al., 2012), although recently it has been suggested that this information actually refers to another fruit from the Cucurbitaceae family - C. melo (Zohary et al., 2012: 155). The latter has been recorded in archaeological material from the Bronze Age in Egypt, Greece, and Mesopotamia (Zohary et al., 2012: 155). Whichever of those plants was preserved in the analysed material, they both produced large, watery, ready-to-eat fruit.
An annual plant from the Fabaceae family, pea, in this case described as Pisum sp., perhaps was cultivated. Most probably the seeds of pea plants were the part used; they contain $25-50 \%$ protein and can be used for human consumption or as a concentrated feed for livestock. They can also be ground into flour and added to bread dough. The whole plant can also be used as green feed or hay and green fertilizer (Dzieżyc, 1967: 108; Körber-Grohne, 1988).

The majority of wild herbaceous plants preserved at the site in Madinnat Ilbīra are species that grow today in ruderal habitats, and this suits the nature of the site. However, it cannot 
be ruled out that in the Middle Ages these plants were grown in home gardens (PeñaChocarro and Pérez-Jordà, 2019). Some of the discovered species could have been of use. Most probably the wild plants that were gathered included the soft fruit of wild strawberry (Fragaria vesca), suitable for direct consumption and sometimes for making jam (Tardío et al., 2006). Others such as Hypericum perforatum, Portulaca oleracea and Malva sylvestris could have been used as edible and medicinal plants (Picchi and Pieroni, 2005; Tardío et al., 2006; Bosi et al., 2009). Consumption of unripe fruits of common mallow, called panecillos ("little bread"), which have a nice nutty flavour, was once common in Spain, particularly among children. The leaves and stalks of that and other mallow species are also eaten in stew. Nowadays that is not such a common practice, and in practice is limited to Andalusia. Malva sylvestris flowers were used for making herbal tea and liqueur (ratafia) (Tardío et al., 2006), and purslane was eaten cooked or raw (Bosi et al., 2009).

The fossil material from the discussed site contained tree remains as charcoals. These were mainly residue of wood fuel collected directly for that purpose. Possibly the scrap from production of household items was also used as fuel, but in the burnt wood assemblage there were no identifiable remains of any worked material that would unequivocally indicate such use of wood.

\section{CONCLUSION}

For many years, research into the past of urban settlement centres has been very high on the archaeologists' agenda for Muslim Spain. One such site is Madinnat Ilbīra, a town characterised by its densely sited stone architecture. Our preliminary results from archaeobotanical analyses of organic remains recovered from the site indicate that the plant diet of the town's inhabitants at that time was very varied. They used at least three species of cereals: Triticum durum vel $T$. aestivum, $T$. dicoccon and Panicum miliaceum, although older research indicates that they also used Hordeum vulgare grain (see above). They also used other crop plants such as Papaver somniferum, Vitis vinifera, Cucumis sativus vel C. melo and perhaps Pisum sp. Wild plants from natural and anthropogenic habitats probably were gathered and used for various purposes as well. Fresh Fragaria vesca fruits were definitely consumed. Other plants that may have had a role in the local diet include Hypericum perforatum, Portulaca oleracea and Malva sylvestris. Those species could provide herbal material to be used as medicines. Wood from various tree taxa was collected and stored as fuel. These first results suggest that, as at other sites in the region, the crop spectrum was broad and the use of wild plants was varied.

\section{ACKNOWLEDGEMENTS}

The project ("Madīnat Ilbīra - the predecessor of Granada. The medieval Umayyad and Mozarabic town in the Iberian Peninsula") was carried out at the Institute of Archaeology and Ethnology of the Polish Academy of Sciences as part of research funded by the National Science Centre (grant no. 2013/11/B/ HS3/02065), in cooperation with the University of Granada. Many thanks to the persons involved in the project and specially in the excavations: Prof. Dr. Antonio Malpica Cuello, Dr. Guillermo Garcia-Contreras Ruiz, Dr. Wojciech Filipowiak, Cristina MartínezÁlvarez M.A. and Karolina Kokora M.A.

We thank Professor Dr. hab. Lucyna Śliwa, Dr. hab. Agnieszka Wacnik (professor IB PAS) and Dr. Magdalena Moskal-del Hoyo for granting us access to the reference collections held by the Department of Palaeobotany of the W. Szafer Institute of Botany, Polish Academy of Sciences in Kraków.

The authors want to express their gratitude towards anonymous reviewers for valuable comments and proofreading.

\section{REFERENCES}

Bates, D.M., Robinson, R.W., 1995. Cucumbers, melons and water-melons. In: Smartt, J., Simmonds, N.W. (eds), Evolution of crop plants. Longman, Harlow, 2nd ed., pp. 89-96.

Bosi, G., Guarrera, P.M., Rinaldi, R., Bandini Mazzanti, M., 2009. Ethnobotany of purslane (Portulaca oleracea L.) in Italy and morphobiometric analyses of seeds from archaeological sites in the Emilia Romagna Region (Northern Italy). In: Morel, J-P., Mercuri, A.M. (eds), Plants and Culture: seeds of cultural heritage of Europe. Studio tutela e fruizione dei Beni Culturali 3, Centro Universitario Europeo Per I Beni Culturali. Ravello, pp. 129-139.

Buxó, R., 2007. Crop evolution: new evidence from the Neolithic of west Mediterranean Europe. In: Collegde, S., Conolly, J. (eds), The Origins and Spread of Domestic Plants in Southwest Asia and Europe. University College London Institute of Archaeology Publications. Left Coast Press, Walnut Creek, California, pp. 155-171. 
Buxó i Capdevila, R., Alonso, N., Canal, D., Echave, C., González, I. 1997. Archaeobotanical remains of hulled and naked cereals in the Iberian Peninsula. Vegetation History and Archaeobotany 6, 15-23. DOI: https://doi.org/10.1007/BF01145882

Cappers, R.T.J., Bekker, R.M., Jans, J.E.A., 2006. Digital Seed Atlas of the Netherlands. Groningen Archaeological Studies. Barkhuis.

Cappers, R.T.J., Neef, R., Bekker, R.M., 2009. Digital Atlas of Economic Plants. Parts: 1, 2a, 2b. Groningen Archaeological Studies. Barkhuis.

Carrión Marco, Y., 2005. La vegetación mediterránea y atlántica de la península Ibérica. Nuevas secuencias antracológicas. Servicio de Investigación Prehistórica, Serie de Trabajos Varios 104. Valencia.

Chabal, L., Fabre, L., Terral, J.-F., Théry-Parisot, I., 1999. L’Anthracolgie. In: Ferdiére, A., BourquinMignot, Ch., Brochier, J.-E., Chabal, L., Crozat, S., Fabre, L., Terral, J.-F., Théry-Parisot, I. (eds), La Botanique, Collection "Archéologiques". Ed. Errance, Paris, pp. 43-104.

Collegde, S., Conolly, J., 2014. Wild plant use in European Neolithic subsistence economies: a formal assessment of preservation bias in archaeobotanical assemblages and the implications for understanding changes in plant diet breadth. Quaternary Sciences Reviews 101, 193-206.

Decker, M., 2009. Plants and Progress: Rethinking the Islamic Agricultural Revolution. Journal of World History 20/2, 187-206.

Dörter, K., 1968. Das Bestimmen der Samen von Gräsern and Schmetlerlingsblutelern. Veb Deuscher Landwirtschaftsverlag, Berlin.

Dzieżyc, J., 1967. Podstawy rolnictwa. Państwowe Wydawnictwa Rolnicze i Leśne. Warszawa.

Esau, K., 1973. Anatomia roślin. Państwowe Wydawnictwa Rolnicze i Leśne. Warszawa. (collective translation edited by H. Teleżyński).

Espinar Moreno, M., 2016. Medina Elvira. Ciudad para la arqueología Granadina. Universidad de Granada, Granada.

Gómez Moreno, D.M., 1888. Medina Elvira. Reprint Grupo Artes Unidades, Granada 1986.

Gurriarán Daza, P., Sáez Rodríguez, Á.J., 2002. Tapial o fábricas encofradas en recintos urbanos andalusíes. In: Martinez Enamorado, V., Torremocha Silva, A. (eds), En II Congreso internacional, La ciudad en al-Andalus y el Magreb (Algeciras). Fundacíón el Legado Andausi, Granada, pp. 561-625.

Hanelt, P. (ed.), 2001. Mansfeld's encyclopedia of agricultural and horticultural crops. 1-6. Springer, Berlin.

Jacomet, S., 2006. Identification of cereal remains from archaeological sites. Archaeobotany Lab IPAS, Basel University.

Körber-Grohne, U., 1988. Nutzpflanzen in Deutschland. Kulturgeschichte und Biologie. Konrad Theiss Verlag, Stuttgart.
Lityńska-Zając, M. 2008. Usable wild plants in the archaeological record from Poland: selected examples. In: Z. Sulgostowska, J. Tomaszewski (eds) Man - Millennia - Environment. Studies in honour of Romuald Schild. Institute of Archaeology and Ethnology Polish Academy of Sciences, pp. 107-112.

Lityńska-Zając, M. 2018. A Man and a Plant: Archaeobotany In: E. Piskin, A. Marciniak, M. Bartkowiak (eds). Environmental Archaeology: Current Theoretical and Methodological Approaches. Interdisciplinary Contributions to Archaeology. Springer, pp. 75-110.

Lityńska-Zając, M., Wasylikowa, K., 2005. Przewodnik do badań archeobotanicznych. Vademecum Geobotanicum J.B. Faliński (ed. of series). Sorus. Poznań.

Malpica Cuello, A., 2011. La ciudad Andalusi de Ilbīra. $\mathrm{Su}$ formación y desarollo. In: Gomes, M.V. (ed.), Cristãos e Muşulmanos na Idade Média Peninsular Encontros e Desencontros. Instituto de Arquelogia e Paleociências, Lisboa, pp. 27-49.

Malpica Cuello, A., 2012a. La ciudad de Madinat Ilbira y el poblamiento de la Vega de Granada (siglos VIII-XI). In: Arízaga Bulumburu, B., et al. (ed.), Mundos medievales: espacios, sociedades y poder: homenaje al Profesor Jóse Ángel García de Cortázar y Ruiz de Aguirre, tomo I. Universidad de Catambria, Santander, pp. 681-692.

Malpica Cuello, A., 2012b. La vida agrícola y la ganadería en al-Andalus y en el reino Nazarí de Granada. In: Marín López, R. (ed.), Homenaje el profesor Dr. D. Jóse Ignacio de Vianca y Vieites, Universidad de Granada, Granada, pp. 213-228.

Malpica Cuello, A., 2012c. Madīnat Ilbīra, un proyecto de investigación sobre el Mundo urbano el alAndalus. Debates de Arqueologia Medieval 2/2012, 383-405.

Marinova, E., van Loon, G.J.M., De Meyer, M., Willems, H., 2012. Plant economy and land use in the Middle Egypt during the late Antique/early Islamic period - archaeobotanical analysis of mud bricks and mud plasters from the area of Dayr al Barsha. Reports in African Archaeology 3, 120-136.

Neef, R., Cappers, R.T.J., Bekker R.M., 2011. Digital Atlas of Economic Plants in Archaeology, Groningen Archaeological Studies 17. Barkhuis.

Paris, H.S., Daunay, M-C., Janick, J., 2012. Occidental diffusion of cucumber (Cucumis sativus) 500-1300 CE: two routes to Europe. Annals of Botany109, 117-126. DOI: 10.1093/aob/mcr281

Peña-Chocarro, L., 2007. Early agriculture in central and southern Spain. In: Collegde, S., Conolly, J. (eds), The Origins and Spread of Domestic Plants in Southwest Asia and Europe. University College London Institute of Archaeology Publications. Left Coast Press, Walnut Creek, California, pp. 173-187.

Peña-Chocarro, L., 2013 (unpubl.). Informe preliminar de los restos vegetales de Madīnat Ilbīra In: García-Contreras Ruiz, G., González Castanón, M., Malpica Cuello, A. (ed.), Memoria final. Proyecto de investigación sistemática la ciudad de Madīnat Ilbīra (Atarfe, Granada), Granada, pp. 769-771. 
Peña-Chocarro, L., Pérez-Jordà, G., Alonso, N., Antolín, F., Teira-Brión, A., Tereso, J.P., Montes Moya, E.M., López Reyes, D., 2019. Roman and medieval crops in the Iberian Peninsula: A first overview of seeds and fruits from archaeological sites. Quaternary International 499, 49-66.

Peña-Chocarro, L., Pérez-Jordà, G., 2019. Garden plants in medieval Iberia: the archaeobotanical evidence. Early Medieval Europe. Gardens and gardening in southern Europe 27(3), 374-393. DOI: doi.org/10.1111/emed.12348

Percival, J., 1921. The wheat plant. Duckworth and Co., London.

Picchi, G, Pieroni, A., 2005. Atlante dei prodotti tipici: le erbe. Roma: Agra, RAI-Eri.

Sabato, D., Esteras, C., Grillo, O., Picó,B., Bacchetta, G., 2015. Seeds morpho-colourimetric analysis as complementary method to molecular characterization of melon diversity. Scientia Horticulturae 192, 441-452.

Schweingruber, F.H., 1978. Mikroskopische Holzanatomie. Eidgenössische Anstalt für das forstliche Versuchswesen, Kommissionsverlag Zürcher AG, Zug.
Schweingruber, F.H., 1982. Mikroskopische Holzanatomie, Komisionverslag/F. Flück-Wirth. Internationale Buchhandlung für Botanik und Naturwissenschaften, CH-9053 Teufen AR.

Schweingruber, F.H., 1990a. Mikroskopische Holzanatomie. Formenspektren mitteleuropäischer Stammund Zweighölzer zur Bestimmung von rezentem und subfossilem. Eidgenössische Forschungsanstalt für Wald, Schnee und Landschaft, Birmensdorf.

Schweingruber, F.H., 1990b. Anatomie Europäischer Hölzer. Paul Haupt Berne und Stuttgart Publishers, Bern-Stuttgart.

Tardío, J., Pardo de Santayana, M., Morales, R., 2006. Ethnobotanical review of wild edible plants in Spain. Botanical Journal of the Linnean Society 152, 27-71.

Watson, A.M., 1983. Agricultural Innovation in the Early Islamic World: The Diffusion of Crops and Farming Techniques, 700-1100. Cambridge Univeristy Press, Cambridge.

Zohary, D., Hopf, M., Weiss, E., 2012. Domestication of plants in the Old World. Oxford University Press, Oxford. 